\title{
2 New Institutions for a New Development Model
}

\author{
Dwight H. Perkins
}

\section{Introduction}

If China's economy and per capita income is to continue to catch up to the levels of the world's high-income economies, China will require a different approach from the model that has dominated its extraordinary development over the past three plus decades. The model of the past in essence involved three basic components during these three decades, and a fourth component during the most recent decade. The first component involved the dissolution of the Soviet-style system of centrally planned command economy and collective agriculture and replacing it with an economic system governed to a large degree by market forces. The second component was the opening of the economy to foreign trade and foreign direct investment, and the rapid expansion of manufactured exports in the growing manufacturing sector. Most of the dynamism in this manufacturing sector came from the domestic and foreign private sectors, together with township and village enterprises that first were collectively owned and later mostly privatised. The third component facilitating the rise of export-oriented manufacturing was the shift of a large part of the rural labour surplus to urban industry and services, a shift that helped keep wages low and labour-intensive manufactured exports competitive.

Beginning to some degree during the world financial crisis of 1997-1998, the fourth component involved the massive expansion of infrastructure investment and the equally rapid expansion of urban housing investment, in effect removing the last major feature of a Soviet-type system that neglected both housing and transport infrastructure. This last component was made necessary, to a large extent, not only by the weaknesses of housing and transport, but also by the fact that the labour-surplus economy produced low levels of household consumption as a share of GDP. This low share in turn necessitated an unprecedented rise in the share of investment in GDP in order to maintain a high rate of GDP growth. ${ }^{1}$

These components of the post-1978 economic model produced more than three decades of high GDP and per capita income growth and created what, in many respects, is a first world infrastructure. Institutional change, however, mostly

1 For my views on how inadequate aggregate demand, represented by low household consumption as a share of GDP, necessitated the large infrastructure and housing investment program, see Perkins 2012. 
involved the dissolution of the institutions of the Soviet-style system and the partial dissolution of some controls, such as the household registration (hukou) system that had been used to restrict rural to urban migration. The incomplete dissolution of the regulations of the centrally planned command economy and of the household registration system left a large residue of regulatory controls administered by government officials who retained much of the discretionary authority of the old system. Only now, in the privatised market context, these officials had far wider latitude for discretion than under the old, tightly controlled, command system.

What is required going forward is a different system for controlling the economy, a system that can build on some of the institutions that have begun to develop, but requires replacing or substantially modifying many of the other institutions that continue to govern China's economy and society. In this chapter I focus on two areas where fundamental changes in these institutions are required, and briefly discuss a third area where the outlines of what needs to be done are well known and progress is already well underway. The first of these areas involves a variety of interrelated institutions, including the regulatory system, the nature of the political system as it relates to government economic decision-making, the legal system, the land ownership system and inadequate decentralised sources of government revenue. These systems, as they operate today, are responsible for a large share of the widespread corruption that threatens political stability and hence economic performance. The second area of interconnected institutions that will be discussed involves the relationship between urbanisation, the social welfare system, and the changing Chinese demographic structure. The third area I will label 'technical institutions' for lack of a better description. This involves continued modernisation of the financial system, the steady improvement and expansion of research and development in engineering and the sciences, the continued upgrading of the universities, and other institutional changes designed to maintain a high rate of growth in productivity.

\section{Regulation, Politics, Law and Corruption}

The dismantling of the Soviet-style system of centrally planned commands over the economy has left an extensive residual of regulations governing all aspects of economic activity both public and private. For example, access to land on which to build a factory or office tower is controlled by urban governments; large-scale investments must be approved by the National Planning and Reform Commission, and lesser projects must be approved at lower levels of the planning hierarchy; and, access to electricity is regulated as is access to any other utility that is controlled by local governments. Then, there are the regulations that 
all countries have that are designed to make sure that a building is safe for its occupants, that companies are fair to their workers, or that a factory doesn't pollute its neighbourhood. All countries, for example, have customs authorities that determine whether and with what taxes goods and services can enter the economy.

For the past decade, the World Bank has attempted to calculate a number of measures designed to estimate the ease or difficulty of doing business in each country. In 2013, the World Bank ranks China 91st out of 185 countries, which, by itself, does not seem so bad, except that countries only ten or so places below China include Zambia, Papua New Guinea, and Pakistan - countries that most would consider highly corrupt and difficult places in which to do business. China, to be sure, has been steadily improving its regulatory environmentit ranks 12th out of the 50 countries that have made the most progress in improving their regulatory environment (World Bank, 2012: 9). China ranks well, or fairly well, at enforcing contracts, registering property, and trade across borders (customs) (19th, 44th and 68th respectively), but poorly, or abysmally, with respect to getting credit (70th), resolving insolvency (82nd), protecting investors (100th), getting electricity (114th), paying taxes (122nd), starting a business (151st), and dealing with construction permits (181st). Given the vast amount of construction that has gone on in China during the first dozen years of the twenty-first century, the last number is particularly striking.

The fact that China ranks among the worst five countries in construction permits, but has by far the most construction activity of any country in the world in recent years, presents a paradox. In China it takes a long time to get the necessary permits (270 days) (in Singapore it is 26 days) and there are a large number of procedures involved (28) (Hong Kong requires six procedures). The number of procedures puts China near the bottom, with the worst performers on this measure, where only nine countries have more procedures, although the length of time required to receive a permit in China is well below that of the worst ten performers, which range from Mozambique at 377 days to Haiti at 1,129 days. The cost of obtaining a permit is also high for China, at 3.75 times the country's per capita income, but that is far below Zambia at 17 times, or Chad at 51 times per capita income.

This paradox of obstructive procedures, but large amounts of construction, is no doubt partly due to the fact that companies can make significant profits from construction (and in many other areas of business) in China, and so it is worth the wait and the expense. But it is also likely that the permitting process is predictable for those with the right connections and the willingness to do what is necessary, above or below the table, to get through that process. What is true for construction permits is also true for a wide variety of other regulatory 
barriers in China. It is profitable once one has gotten through them and the path through them is predictable at least as long as one has the right connections or is willing to develop them.

There are straightforward ways of trying to eliminate some of these regulatory obstruction issues, although they do not by themselves fully solve the problem. One key is to remove as much discretion as possible from the domain of the officials who decide whether to issue a license or permit or not. The rules for issuance should be clear and public, and the process itself should be transparent. If an applicant complies with all of the rules, the permit should be issued automatically. To prevent delaying tactics by officials as a means of extracting rents, there should be time lines that establish the point in the process at which a permitting agency must make a decision. The process of what is required and where a given application stands should be accessible online, so that an applicant (and a government monitoring agency) can readily check on the progress of an application. For straightforward procedures, such as issuance of a driver's license, this method will go a long way toward solving the problem of delays by the issuing official that are designed to extract rents. Where the procedure involves more complex problems, however, requiring official judgement as to the desirability of the project or the character of the applicant, these simple procedures are not likely to be sufficient to solve the issue of excessive delays.

When judgement and discretion on the part of the issuing office are involved, the problems of removing regulatory barriers are much more difficult. In China, the problem begins with the fact that the Chinese Communist Party and its key members, at both the local and higher levels, have discretionary power over a variety of issues, including many that determine whether a company or individual can receive permission to go ahead with a project or program. If the Party leadership strongly supports a project or program, it can cut through regulatory barriers and get the necessary authorisation to proceed. One problem, however, is that the Party can operate on both sides of a transaction. Local and higher level party officials can have a major say in the appointment of the government official in the regulatory office, and a similar say in the appointment of the enterprise manager (or party secretary) in the application for regulatory relief. Similarly, in the past, in applications for project funding, local party officials have had an influence over both the local branch of one of the national banks making the loan and the managers of the company or the local government officials applying for the loan. When there is more than one applicant for a single permit, the applicants with the best connections to local or higher level officials have an obvious advantage. 
From the viewpoint of the applicant for permits or regulatory relief, there are a variety of solutions to overcoming another applicant's political advantagethey can, for example, make illegal payments to the official or to others with influence over that official, they can hire a close relative of the official or of the Party secretary of the official and pay that person a high salary or give them a large consulting contract. China has no monopoly on these practices - they are common throughout the world, including in most high-income countries. Straightforward payment of bribes can be dangerous for both the payer and payee, and official malfeasance of this sort can sometimes be identified by requiring officials and other senior political people to fully report their financial and other assets to a higher authority; this practice has been used to a degree in China. In a country such as China, however, where success or failure of a project or enterprise can depend on making one's way through a maze of regulations, there are circumstances in which there is no need for formal bribes. Placing a person with powerful political connections on the board of directors, or in some other conspicuous position, can have a equivalent influence. The individual so employed may not have to actually contact the regulatory officials dealing with the company, or do anything whatsoever, to overtly help the company with the regulators. The mere knowledge that that individual is supporting the company will influence a lower level regulator to try to be helpful. The possibility that the powerful consultant or member of the board of directors might criticise the regulatory official and thereby damage or end that official's career is sufficient. Many officials will not be willing to take the chance that this will happen.

It is not surprising, therefore, that the family members of some high party officials have ended up making large fortunes. Many of these officials have no doubt made these incomes because they have skills that have contributed in a technical sense to the companies they work with, but there are examples where the main thing the family member brings to the table is his or her political connections. The problem does not occur, however, only at the top of the pyramid; it exists right through the system, down to the local level.

There are three ways of trying to deal with the relationship between regulatory power, political influence, and rent seeking. One way, which has dominated Chinese practice throughout the last three decades, is to have stiff punishments, including the death penalty, for financial crimes. This is problematic in a highly regulated economy, such as China's, where all officials have a significant discretionary decision-making power, it is difficult to find and convict enough law breakers to make a difference to the overall problem. China has a population of 1.3 billion, comprising 80 million party members, tens of millions of officials, and over 2000 county-level governments, plus even more numerous townships and villages. It is noteworthy that China has prosecuted high level officials, and not just low level rent seekers, but the task of discovering whether a crime 
of corruption has actually occurred, or whether it was just the excessive use of political influence, receipt of a personal gift that was a little too large, or a trip that was a little too lavishly funded. To an extent, the massive surveillance system that existed in the 1960s and early 1970s could control these forms of corruption, but at the price of far worse abuses of power in non-financial areas. Short of massive police surveillance, it is difficult to prove that a crime of corruption has been committed. Going after officials who are only suspected of malfeasance, but where firm proof is missing, leads to other kinds of abuses. Inevitably it is seen as motivated by a desire to eliminate political opponents.

The second straightforward method for controlling this kind of corruption is to reduce the number of regulatory barriers that companies and individuals must get through in order to prosper. The fewer regulations there are to deal with, the less a company needs to spend in time and money in getting through those regulations. A well-functioning market system can control many forms of behaviour that harm the economy without the need for regulation of any kind, but even in the most market-oriented economy, Hong Kong being a good example, there is a need for some regulations. But, if one reduces the number of regulations and hence the opportunities for rent seeking, it is easier for public security and prosecutors to identify and try the smaller number of violations that do occur. It is no accident that the two economies with the lowest level of corruption in Asia, Singapore and Hong Kong, are the economies that are most regulated by market forces rather than government regulations. Even in Hong Kong, a market economy did not immediately diminish corruption in some areas, notably in the police, where a high degree of discretionary authority was inherent in the job. In Hong Kong it also took a major anti-corruption drive orchestrated by the Independent Commission Against Corruption that was founded in 1974, but the task before the commission was a simpler one than that faced by any commission responsible for the People's Republic of China.

Thus, there must be a third way of combating corruption, and a critical step in that third way would be to change the role played by the Chinese Communist Party in the economy. In essence, as long as the Party plays a role of determining the rules of the economic system, follows that by appointing most of the government officials that administer that system, and then also directly appoints, monitors and replaces those leading major producing units in that economy-including all enterprises with a substantial degree of government ownership - the system will be riddled with conflicts of interest. Success in that system will depend more on one's political relationships than on anything else.

If the Party is to get control of corruption, therefore, it has to remove itself from the direct administration of the central and local government and of large parts of the economy. There is a precedent for doing this in recent Chinese history. The Party effectively removed itself from the day-to-day management 
of agricultural production when it abolished the Rural People's Communes. The privatisation of large parts of the urban economy, both industry and services, has also meant that decision relating to management personnel in this sector are mainly made by the private owners, foreign and domestic. Most large private units have party committees and, no doubt, many party members, but the Party does not determine company priorities and day-to-day management in any direct way. Even in the state-owned enterprises, including those shareholding enterprises where the majority shares are held by government, there has been some success in separating the role of the Party from the technical operation of the enterprise. What is needed is to complete the process of removing the Party as the main vehicle determining senior employment throughout the system. The Party would instead become a body that set the rules of the system, gave it its overall direction, and then monitored whether officials and economic units were following the rules and implementing the broad goals. It would play a role more like the traditional censorate in the imperial dynasties, but with a broader mandate than that of the censorate because it would also replace the policymaking role played by the emperor.

If the Party were to remove itself from the day-to-day management of the economy and society, certain other institutions would have to be strengthened from what they are today. Foremost among these institutions is the legal system. China has made progress in rebuilding the legal system after its dismantling during the Cultural Revolution, but it is far from adequate for what would be required in a system where party leaders and government officials were no longer the ultimate settlers of disputes between economic parties. In a full market economy, most economic disputes are handled through the courts, which are largely independent of the parties to those disputes, including government officials and units. By having independent, competent, and honest judges deciding disputes, political considerations are largely eliminated from the verdict, which is decided on its legal merits.

The contemporary legal system in China is neither independent of higher political authority, fully competent or consistently honest. The easiest to fix is competency. When the legal system was reconstituted after the Cultural Revolution, there were few people trained in the law and, hence, the judges often had no legal background. In 2010, China's law schools graduated 26,165 lawyers (NBS 2011: 746) and the total stock of lawyers numbers in the hundreds of thousands. Making judges independent so that they can make decisions strictly according to the law and the facts of the case is far more difficult. Higher level government and party officials often feel they can overrule or ignore court decisions; even company managers with sufficient political influence can often do so. Furthermore, the judges are appointed by the government and the Party, and can be removed if they do not fulfil the expectation of carrying out the goals 
of the Party. Truly independent justices must have a credible commitment to long tenure, as long as they themselves do not violate the law, and they cannot be removed for a verdict disapproved of by higher authorities. In the absence of that kind of commitment, judges will be influenced by the political winds blowing at any given moment and the legal system will be regarded as unfair.

It will probably be a long time before courts in China are made independent of politics, especially in areas where there are perceived threats to the state or the rule of the Chinese Communist Party, but the Party has no obvious interest in letting political considerations govern economic verdicts. Individual government and party members will retain their own interests, including those of the rent-seeking variety, but those interests can be a bigger threat to the rule of the Party than judges who are sometimes seen as too independent. If one can remove overt political biases from the legal process, it will also be easier to remove the problem of corrupt courts. Paying judges well and monitoring their personal assets would also go a long way toward eliminating judicial decisions driven by corrupt practices.

If China is ever to get full control of corruption, and to have a functioning economic system driven by market forces combined with regulations designed to compensate for real market failures, therefore, there are fundamental changes needed in the institutions governing China's economy and society today. The changes are interrelated: there needs to be a substantial reduction in the role played by government regulations as contrasted to market forces, and the discretionary authority of those government officials in implementing those regulations must be greatly reduced or eliminated. There must be a further withdrawal of the Party from the day-to-day operation of government agencies and economic units and a focus of the Party, instead, on setting the goals for the system, translating those goals into legislation, and monitoring progress in their implementation, but doing so from outside government agencies and economic units, not as day-to-day managers within them. There are other kinds of political institutions that could play this role, but most of them are part of China's future, rather than its present. Failure to make major progress in these areas will foster a continued rise in corruption that will steadily undermine the ability of the Party to govern the country.

\section{Rural Land and Local Government Revenues}

A major source of political instability in China over the past decade and longer has been the perceived corruption of the process whereby agricultural land is taken from farmers, at low prices, and sold to developers at much higher prices with the fund from difference between these two prices going to local 
governments, and sometimes to local officials for personal use. Unlike the issue of the role of the Party being overly involved in the day-to-day operation of government agencies and economic units, this problem of the distribution of rural land can be solved to a substantial degree by technical reforms that do not involve a change in the role of the Party, or anything else that would be politically sensitive.

The first step to solving this problem would be to allow land to be sold on the open market at prices set by that market, and giving the farmers tilling that land either ownership or long-term user rights, with the right to sell the land or their user rights, similar to the system that allows companies to lease urban land. Government officials would then no longer be able to take land away from the farmers without paying them a fair market price, or, if they managed to do so, it would be seen as theft and prosecuted as such. There would still occasionally be the need for what is known in many high-income countries as 'taking the land by eminent domain' to serve a public purpose, such as building a road, but there would be a reference price set by the market, not by administrative rule. Ideally there would also be independent courts to determine whether the land was taken at a fair price and for a legitimate public purpose or not.

If one pays a fair price for the land, and if one allows land to be taken by eminent demand, however, there need to be two additional changes in related institutions. The first such institutional reform would be a need to change and expand the social safety net as it affects not only the rural population, but also the population registered as rural that is in fact working in non-agricultural occupations, mostly in the cities. The issue of urbanisation and rural migrants (discussed below) is relevant here because rural land in China is an important part of the safety net for these migrants, as well as those living in rural areas. Allowing migrants to sell their land rights gives them funds that will ease their permanent transition to urban life, but it will also remove the fallback position of returning to their land, something that many have used when employment in the cities has fallen through. A new fallback position or safety net is required.

The second necessary institutional change is to provide local governments with sources of revenue commensurate with the level of expenditures that they are required to make. In recent years, notably during the large stimulus spending designed to maintain high GDP growth in the face of a world recession, the central government pressured local governments to carry out and pay for a large part of this stimulus. That, together with the fact that local government officials get promoted in part on the basis of the GDP growth in their area, led local governments to run up debts that have been officially estimated at close to RMB10 trillion, but unofficially at perhaps twice that figure. It is now widely recognised that the local governments do not have the revenue sources to pay for these expenditures or to service these large debts, even if they continue 
to earn revenue by paying low prices for local land and then selling the land to developers at a much higher price. If the land market is reformed and land prices become true market prices, this source of local revenue will disappear, thereby increasing the revenue shortfall.

One modest way of raising local revenues would be to charge a land tax on developer land other than agricultural land. One could also tax agricultural land, but the government only recently abolished the agricultural tax as part of an effort to increase the disposable income of the rural population. The other way is for the central government to take over more local expenditures or, alternatively, expand the subsidies it pays to local governments from central revenues. Whatever the ultimate solution, continuing to allow local governments to buy land cheaply and sell it at high prices must end if China wants to maintain rural stability.

\section{Urbanisation, Migration, Ageing and the Hukou System}

China, in many respects, is following the pattern of urban development that is characteristic of all countries that have achieved middle-income status and are heading toward becoming high-income nations. China, having spent the two decades prior to 1978 trying to tightly restrict the growth of the urban population, is rapidly becoming a nation where the increasing majority of the population is no longer involved in farming, and a large share of that nonagricultural population now resides in cities. Officially, the registered urban population in 2011 was 51.3 per cent of the total, up from only 17.9 per cent in 1978. The figure for 2011 includes some migrants (those who had been in a city for over six months), but excludes others. The urban figures also include some farmers who reside within the urban district, but this would be a small number in the major cities today. The population that is still involved in farming is much smaller than the population listed as residing in rural areas-employment in agriculture in 2011 was under 35 per cent of the population, down from a little under 70 per cent in $1978 .^{2}$ Most of the people doing farm work as their major occupation today are over the age of 40 .

There are three major challenges connected with the fast pace of urbanisation that China faces today and going forward over the next one or two decades. The first is keeping the growth rate of urban employment at a level sufficient to absorb the increases in the labour force, both rural and urban. That number

2 The official figure for the primary sector in 2011 is 34.8 per cent, but this includes employment in mining (NBS 2012). 
is perhaps 14 million per year, if most of the increase in the labour force is absorbed by urban employment. ${ }^{3}$ Since there will be close to ten million urban workers reaching retirement age and leaving the labour force each year, the net increase in employment needed to absorb these new entrants into the labour force is small, relative to the past, and will become a negative figure over time. When one adds the fact that the share of the service sector in this new employment is likely to rise and that of manufacturing begin to fall, the labour market will remain tight and wages will rise. The service sector will grow more rapidly because China has already reached the point where, in most countries, manufacturing output as a share of GDP and employment in manufacturing falls even more rapidly than the share of output. ${ }^{4}$ Thus, if China maintains a GDP growth rate of six or seven per cent per year for another one or two decades, wages should continue to rise, possibly and hopefully faster than GDP.

The second and third challenges are not so easily met, and they will require fundamental changes or improvements in the institutions currently in existence. The second challenge is the need to entirely get rid of the household registration system (the hukou system) as it is currently configured. The system is no longer used to restrict the entrance of workers into the cities, but key features of the system ensure that the population that is working, but not registered, in the urban areas is discriminated against in ways that are ultimately harmful to Chinese society. There is widespread acknowledgement that this is the case among a wide range of Chinese scholars and others who have thought about the problem. There are even a few urban districts that have taken steps to deal with important aspects of the issue, mainly cities that seek to attract migrants rather than repel or ignore them.

The problem with the way the current system is administered stems from the fact that there is little affordable housing of any quality that is available to migrant workers from the countryside. That in turn leads workers to live on construction sites, others are crowded into a single rented room in a distant suburb, and young women often reside in factory dormitories. The poor housing conditions also leads large numbers of migrant workers to leave their children in their home village with their grandparents, instead of having them attend generally higher quality urban schools that would better prepare them for urban life. The government now makes urban schools open to migrant children,

3 There were 222 million people aged 14 and under in 2011, or an average of 16 million for each year of age. A few of these people, when they finish schooling at whatever level, will stay in agriculture and a few will not enter the labour force. I have assumed that these two categories would amount to two million people per year, with the remainder looking for work in the urban workforce.

4 Manufacturing employment in 26 OECD countries, plus Taiwan, began declining on average when they reached a per capita Purchasing Power Parity Income of US\$13,300 (or within a range from US\$7,000 to US\$17,000 per capita) (Eichengreen et al. 2012: 87). This decline in manufacturing employment is often referred to as deindustrialisation although manufacturing output in most cases continues to grow. 
but few can afford the high fees and related expenses that are associated with most of the urban schools. The central government has a large public housing program for the registered urban poor, but, on the national level, there is still no such program for the migrant population. There is also a greatly improved program for rural and urban health insurance, but again the migrant population has to return to the villages where they are registered to take advantage of this program. Finally, the university entrance quotas are based on a national exam that is biased in favour of registered urban residents, what is in effect a reverse affirmative action program for the well off.

Few, if any, of these migrants will return to farm work. There are still far too many workers in agriculture and that keeps incomes for farm work low, although they have certainly risen substantially over the years. The children of these migrants are also not going to be farmers. The system needs to figure out ways to support rural migrants to the cities with housing, access to schooling for their children, and a social welfare and pension system that includes them. And these systems or institutions need to be created over the next one or two decades. To accomplish such an ambitious goal, the government following standard Chinese practice will have to experiment with what kinds of housing would be appropriate, what kinds of health care will be both affordable and will meet as many needs as possible, and what kinds of education would also be affordable and meet the needs of migrant families. Creating these institutions is not a simple matter. As the United States among others has demonstrated, high-rise apartment buildings may not work as well for poor migrant families as for the urban middle class. Similarly, the educational needs of children from the rural areas, where their parents had limited education, are different from the needs of urban families with well-educated parents, to mention only two areas of potential differences in the kinds of support required for migrants.

The third challenge has some things in common with the second challenge, but it is relevant to the entire urban population and not just to recent migrants from the countryside. It is the challenge of China's ageing population in the context of a society that is becoming mostly urban. There are two aspects to the impact on Chinese society of a rapidly ageing population. The one that typically gets the most attention is the fact that in China, the enforcement over a long period of the one child family policy has created a situation in which the old-age dependency ratio will rise rapidly, and fewer and fewer people of working age will be available to support those who have retired from the labour force. The second aspect is that urban life, in most countries, typically ends the practice of several generations of one family living under the same roof (or in adjacent houses in villages built by the families themselves). Rather, grandparents live separately from their adult children and the nuclear family 
is the norm. The working-age children may in fact live in a different city from their grandparents, something that is common in most high-income countries. Traditional ways of taking care of ageing grandparents thus no longer apply.

China's population's overall dependency ratio has fallen steadily over the past three decades, and has only recently begun to level off. This is as a result of the one child family policy which caused the share of children below working age to fall sharply, while the share of the elderly outside the labour force grew rapidly (by roughly 50 per cent over the past two decades), but from a very low level (from 8.3 per cent of the population in 1990 to 12.3 per cent in 2011). The share of children as of 2013, however, has levelled off, and may even rise modestly if the one child family policy is finally abandoned or modified, as many in China are advocating. The share of the ageing will definitely continue to rise, and do so rapidly as people live longer and as China's own 'baby boomers' (the population born after 1949 but before the one child policy) begin to retire. Of the 133 million people who were zero to nine years old in 1950, 94 million are still alive today, are aged 60 to 69 and are soon to be, or already, retired. The next age cohort that was zero to nine years old in 1960 totalled 192 million in that year, 161 million of those were aged 50 to 59 in 2010; many of the women in this group have already retired and the men will soon be approaching retirement. In addition to these people, in 2010 there were 71 million people aged 70 and over still living, up from only 30 million as recently as 1980. And the largest age cohorts of retirees come in the decades immediately after those who were zero to nine years in 1960. In 2010, there were 225 million people at an age (15 to 24) that will make them eligible to enter the labour force, compared to the 161 million in the 50-59, about to retire, age group. Ten years later (in 2020) there will be roughly 225 million in the 50-59, about to retire, age group and the same number in the 15-24, about to enter the labour force, group. (United Nations 2011)

The burden of this demographic change is usually expressed as the dependency ratio that has fewer and fewer people in the work force supporting more and more retirees. In a rural peasant society, however, this burden is mainly one of more mouths to feed around the dinner table, most of the food comes from the family's land and they build their own houses on that land. This is hardly an ideal existence, since the cultivated land is small and illness can make it difficult to cultivate even that small amount. Generally, there have been no institutions that intervene in this process - one either grew enough food and stayed reasonably healthy or one starved and got sick and died.

In an urban environment and in a modern economy, where families are mobile and go where their work takes them, elderly retirees from the workforce must have a steady income to pay the rent on their apartment, buy food from the market, and to pay for other activities. Those other activities are typically more extensive than in a peasant village, in part because more activities in an 
urban environment must be paid for with cash and people in urban centres are also used to a higher standard of living than those in rural villages. For people with sufficient funds, a variety of institutions can be created to meet their needs starting with independent housing but moving on to assisted living facilities and then to nursing homes, hospitals, and hospices toward the end of life. China is creating these kinds of institutions and it is being done commercially for those who can afford it.

The problem is that most urban residents in China, let alone the migrants from the countryside, do not have the retirement incomes that can support institutions of this sort. Many have meagre pensions, or none at all, because the company they depended on did not provide those benefits or it became bankrupt and could no longer honour commitments that it had made in more prosperous times. Thus, China faces the challenge of ensuring that its urban population has an adequate source of income in retirement and a wide range of institutions to support their needs as they age, and a health insurance system capable of paying for it. And all of this has to be created in the next one or two decades, when China will still be a far from rich nation. The one saving grace is that family ties in China remain strong and adult sons and daughters will take responsibility for their parents when they can, but, as countries such as Korea (or the United States before social security and medicare) demonstrate, in the absence of a strong safety net for the elderly, a large number will live out the remaining years of their life in poverty.

\section{Institutions Promoting Growth in Productivity}

The institutional changes that get the most attention from policy makers and the educated public in China are those connected with sustaining a high GDP growth rate. China's potential GDP growth rate will decline from the nine to ten per cent rates of the past three decades, even if China does everything right in the economic sphere. This decline appears to be underway now, but will almost certainly be underway within the coming decade. A major stimulus for infrastructure and housing going forward, similar to what occurred in 20092011, may keep the GDP growth rate up for a few years longer, but this kind of spending at levels similar to the recent past is already facing diminishing returns. Maintaining a high growth rate of, say, six to seven per cent a year over the next one or two decades will require steady and substantial increases in total factor productivity. ${ }^{5}$ High rates of growth of total factor productivity over the first two decades of the reform period were sustained by the steady

5 For a systematic analysis demonstrating the relationship between a continued high growth rate and total factor productivity, see Perkins \& Rawski 2008: 829-86. 
dismantling of the many barriers to efficiency and growth that had been thrown up by the Soviet-type economic system. Going forward, however, productivity growth will depend on the creation of ever more efficient, new and improved economic institutions, not the dismantling of old ones. Creating new and improved institutions is inevitably more complex and more difficult than simply getting rid of institutions that do not work.

The key economic institutions that are needed to sustain a high GDP growth rate are thus those that raise the productivity of both capital and labour. Sustained increases in the efficiency of capital are mainly dependent on steady improvements in the financial system, further reforms of state-owned enterprises in general and those with state monopolies in particular, and in the strategy of development pursued. There is a large literature on how to improve the financial system, and another chapter in this volume is devoted to the subject. It is noted here that China has already moved a substantial distance from a financial system made up almost exclusively of large, state-owned commercial banks that lent mainly to state-owned enterprises. There are many more banks, there are other important financial institutions, ranging from insurance companies to the two stock exchanges and beyond, and privately owned companies and individual citizens have an important degree of access to bank loans. There is still too much politics in lending decisions, and many of those promoting the most innovative enterprises have little or inadequate access to the capital markets. Thus, there are still major improvements possible and, if pursued vigorously, these improvements should substantially raise the efficiency of capital.

Reforming the state-owned enterprises is likely to be a more difficult challenge, in large part because the political power of these enterprises is formidable. It took considerable political courage to implement the major reforms of these enterprises that occurred in the late 1990s. Monopolies produce large profits that benefit powerful people, but they also reduce the incentive to promote efficiency in these critical sectors. The slowing of the massive infrastructure and housing investments will also create a situation where industries, such as steel, will face years of financial difficulties because of earlier decisions to build capacity beyond any plausible future domestic demand. The large state construction companies that have built much of this infrastructure will also have to be cut back. The alternative, such as that followed by Japan, of continuing large state construction projects designed to keep these companies busy will lead to results in China not dissimilar from what has contributed to Japan's anaemic economic growth rate. China's infrastructure investment of the past decade made a major contribution to economic growth and the efficient use of capital, but the number of projects of this sort that will contribute to raising growth and the efficient use of capital is declining. As China moves into an economy that is increasingly dominated by the service sector, the temptation 
to support numerous inefficient service providers at the expense of new, more efficient, service providers, a pattern pursued for years by both Japan and South Korea, also needs to be resisted.

Finally the efficient use of capital depends on getting the right balance between reliance on market forces and the need for some regulatory interventions to correct for important market failures. This chapter began with a discussion of the major issues connected with this challenge, and they are also discussed in the chapters in this volume on the environment and reforms in the financial system.

Improving the efficiency of labour is equally as important as raising the productivity of capital. At the low-skilled end of the labour force, and to a degree for the entire labour force, the need is for healthy and increasingly welleducated workers. There is also a need to remove the remaining barriers to the movement of that labour to its most productive uses. Those issues in essence were the subject of the second major part of this chapter. At the higher-skilled end of the labour force, the main issues have to do with steadily raising the quality of education at the university level in general, and at the postgraduate level in particular. Steady advances in the quality of research produced, whether in universities, companies, or research institutes, is critical for continued growth in the economy. China's progress in this latter area is considerable, but, as per capita incomes rise, sustained economic growth depends increasingly on innovation through research and development, that moves from small improvements in products and production processes to new products and services.

\section{Conclusion}

The challenge facing China over the next one or two decades, and the essence of the new model of growth that is required, therefore, is to create the institutions of a truly modern economy and society. Creating new institutions and fundamentally restructuring old ones is inherently more difficult than the dismantling of inappropriate institutions. It is also more time consuming, and thus contributes with other factors to the slowing of GDP growth that is inevitable as per capita incomes rise and the economy and society become more complex. In most of the areas described in this chapter, where institutional reform is required, China has made major progress. This chapter, however, has focused mainly on economic reforms, and economic reforms usually require accompanying political reforms; the political reforms needed to sustain China's transformation into a modern, high-income society are likely to be an even greater challenge than those in the economic area. 


\section{References}

Eichengreen, Barrt, Perkins, Dwight H. \& Shin, Kwanho, 2012, From Miracle to Maturity: The Growth of the Korean Economy, Harvard University Press, Cambridge.

National Bureau of Statistics of China (NBS), 2011, China Statistical Yearbook 2011, Beijing.

— , 2012, Zhongguo tongji zhaiyao 2012, Statistics Press, Beijing.

Perkins Dwight H. \& Rawski, Thomas G., 2008, 'Forecasting China's Growth to 2025', in Loren Brandt \& Thomas G. Rawski (eds), China's Great Economic Transformation, Cambridge University Press.

Perkins, Dwight H., 2012, 'China's Investment and GDP Growth Boom: When Will it End', in Masahiko Aoki \& Jinglian Wu (eds) The Chinese Economy: A New Transition, International Economic Association, Palgrave MacMillan.

United Nations, 2011, World Population Prospects, The 2010 Revision, online at http://esa.un.org/wpp/Excel-Data/population.htm. 